\title{
Environmental health risk assessment due to radionuclides and metal(loid)s for Igdir province in Anatolia, near the Metsamor nuclear power plant
}

\author{
G. Karahan', E. Kapdan', N. Bingoldag1, H. Taskin', A. Bassari', \\ A.T. Atayoglu ${ }^{*}$ \\ ${ }^{1}$ Cekmece Nuclear Research and Training Center, Küçükçekmece, Istanbul, Turkey \\ ${ }_{2}^{2}$ Istanbul Medipol University, Faculty of Medicine, Department of Family Medicine, Istanbul, Turkey
}

\begin{abstract}
\section{- Original article}

\section{${ }^{*}$ Corresponding author:}

Ali Timucin Atayoglu, M.D.,

atatayoglu@medipol.edu.tr

Revised: May 2020

Accepted: June 2020

Int. J. Radiat. Res., October 2020; 18(4): $863-874$

DOI: 10.18869 /acadpub.ijrr.18.4.853

Background: There have been growing concerns about environmental pollution and public health issues associated with metal(loid)s and radionuclides. As a baseline for monitorisation, radioactivity and specific metal(loid) levels have been measured to investigate the estimated environmental health risks in Igdir province at the Turkish side of the border, in the vicinity of the Metsamor Nuclear Power Plant, an aging nuclear station without primary containment structures. Materials and Methods: Concentrations of radioactivity and accumulation of metal(loid)s in the region were measured and hazard quotient, hazard index, and the excess lifetime cancer risk vaues were calculated according to international methods and standards. Results: Hazard quotient and index values were determined to be lower than the permissible maximum levels. The average estimated excess cancer risk values for terrestrial and cosmic exposures due to radionuclides were calculated as $1.8 \pm 0.9 \mathrm{E}-04$ and $2.4 \pm 0.04 \mathrm{E}-04$, respectively. The average estimated excess cancer risk value for the radioactivity in water was determined as $15.2 \pm 13.6 \mathrm{E}-05$. The mean excess lifetime cancer risk values due to metal(loid) exposure were as $\mathrm{Cr}<\mathrm{Ni}<\mathrm{As}$ in soil and as $\mathrm{Cr}<\mathrm{Cd}<\mathrm{Pb}$ in water. Conclusion: The mean concentrations of selected metal(loid)s and radionuclide activities were below the maximum permissible limits. Relatively low hazard indices suggest that the population is currently not at any imminent health risk.
\end{abstract} E-mail:

Keywords: Environmental health, cancer, metal(loid), Metsamor, radionuclide, pollution.

\section{INTRODUCTION}

Environmental pollution is a major global health threat. Modern technological developments have brought new challenges concerning environmental safety because unlimited industrialization without proper emission controls and pollution abatement pose a risk to human life (1). There are increasing ecological concerns about pollution and global public health issues associated with metal(loid)s and radionuclides, which may have harmful effects on human wellbeing through different retention pathways (2,3). They may cause eco-pollution and health risks, and therefore, exposure to radionuclide materials and certain metal(loid)s are considered objectionable $(4,5)$.

Radioactive substances are defined as materials that contain unstable atoms which produce ionizing radiation through nuclear rearrangement. Radionuclides are radioactive isotopes, and they are widely distributed on earth (6). Some studies in the relevant literature revealed the health impacts of radiation and showed that radiation exposure might increase cancer risk, and it differs with the dose, age, 
gender, and tissues (7,8). Radiation is also accepted as a risk factor for non-cancerous health problems (7). Radioactivity may cause kidney disorders, cardiovascular diseases, and thus induce hypertension; the mortality risk of cardiac problems increases with dose (9-11). Risk of stroke increases to some degree, especially at high doses (12).

A metal is a substance with high electrical conductivity, luster, and malleability, which forms cations, and a metalloid is a chemical element that exhibits semimetallic or semiconductor properties (13). Although it has been diversely defined, the term "heavy metal" usually refers to metal(loid)s having an elemental density $>5 \mathrm{gcm}^{-3}$ and an atomic number $>20$ (14). The diversity of definitions has led to confusion, and some experts in the field suggested even abandoning the use of the term (14). Metal(loid)s may accumulate and disturb function in vital organs by binding to cellular components and disrupt function in vital organs (15), or they can remove the essential nutritional minerals from their location and inhibit their bio -action (16). Metal-toxicity occurs mainly because of their reaction with sulfhydryl enzyme systems (17). They may cause the production of reactive oxygen species (ROS), and expanded generation of ROS can interfere with fundamental antioxidant defenses of cells and cause oxidative stress ${ }^{(18) .}$

Radioactive contamination and metal pollution in soil and drinking waters can threaten human health in time (19). Metal(loid)s are likely to attach organic substances to produce organometallic compounds in sediment (20). Metal(loid)s in the soil can be taken into the body via respiration, ingestion, or skin contact absorption and harm the health (21).

The region potentially carries a critical risk being at the border with Armenia, only $\sim 20 \mathrm{~km}$ away from the Metsamor Nuclear Power Plant, an aging Soviet-era nuclear station without primary containment structures (figure 1). Furthermore, the station is built upon an area prone to powerful earthquakes over magnitude 7.0 on the Richter scale, although the plant was not constructed to resist tremors at that level $(22,23)$. Main pressure parts are worn-out and

\section{4}

outdated, and the waste disposal situation is unclear. There is no waste agreement in place, and the emergency response system and evacuation plans are not available (24). Therefore, the neighboring countries and the European Union are justifiably concerned with environmental health risks (25).

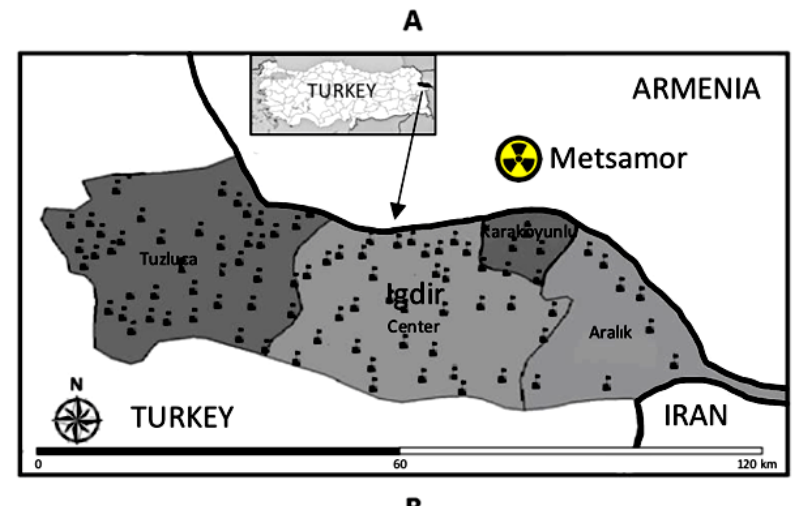

B

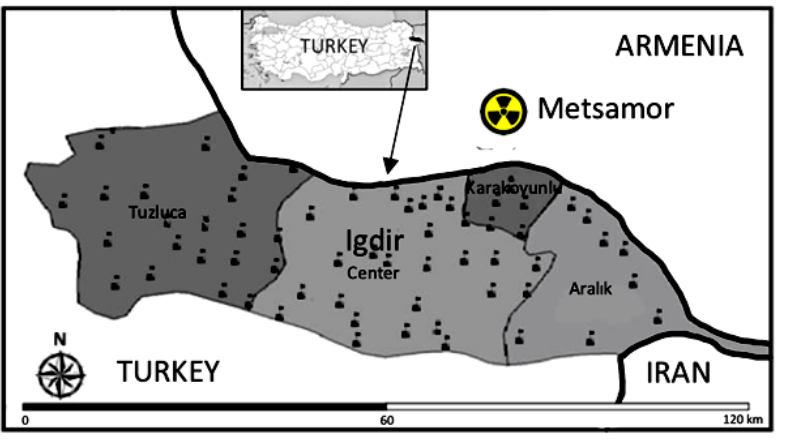

C

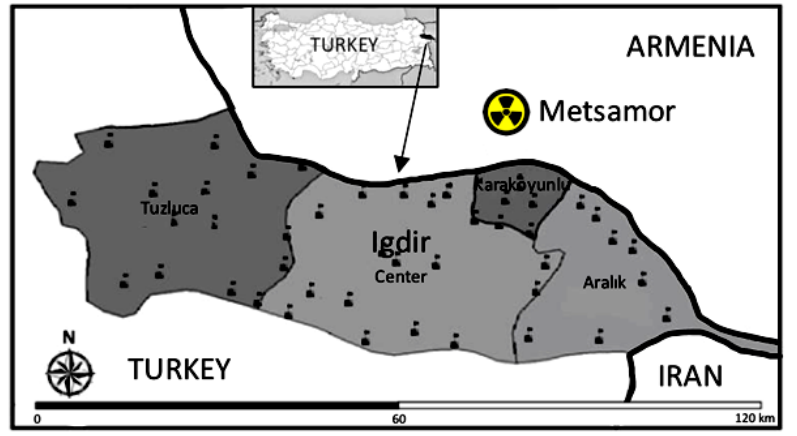

Figure 1. Location of Igdir Province with sampling sites. The region potentially carries a critical risk being at the border with Armenia, only $\sim 20 \mathrm{~km}$ away from the Metsamor Nuclear

Power Plant, an aging Soviet-era nuclear station without primary containment structures. A. Outdoor Absorbed Gamma Dose Rate Measurement Sites B. Soil Sampling Sites C. Water Sampling Sites.

The present study aims to investigate the risk assessment of health risks due to background

Int. J. Radiat. Res., Vol. 18 No. 4, October 2020 
accumulation of radioactivity and metal(loid)s in soil and water in the natural environment of Igdir province in the vicinity of the Metsamor Nuclear Power Plant. The findings obtained in this study are noteworthy because it can serve as a baseline for future efforts to monitor and evaluate the impacts of the Metsamor Plant, considered to pose a high level of risk.

\section{MATERIALS AND METHODS}

For studying the soil radioactivity and terrestrial gamma dose rate, radioactivity in drinking water, outdoor gamma dose rates, and accumulation of metal(loid)s in soil and water, samples were collected from selected sites of Igdir Province. Sampling, sample preparation, and measurements were performed according to international methods and standards $(8,26)$. Igdir Province is in eastern Turkey, located along the borders with Armenia, Azerbaijan, and Iran (figure 1). Igdir is located in the northeastern part of the country, has an area of approximately $9.587 \mathrm{~km} 2$, with a population of 301.766 . The province has four districts. The center of the province is situated at an altitude of about 2000 meters over the sea level, and the altitude all over the province changes between 300 to 3300 $\mathrm{m}$. As geographically, plateaus constitute $51 \%$ of the city. In some plateaus, which are very wide and undulating, small plains and sediment lakes can be seen. There are many threats to drinking water, which may pose a health risk. Water may come from three primary sources: rainwater, surface water, and groundwater. Water samples in this research were collected as drinking water.

A proportional counter analyzed water samples with the gas flow. The geographic coordinates of the sites were determined by Global Positioning System (GPS). ArcMap module of ArcGIS (10.2 version) mapping software was used for plotting spatial distribution maps for the region. Trace element analysis was determined using $\mathrm{x}$-ray fluorescence (XRF) technique. The powdered samples were passed through a sieve and mixed with eluate agate. The samples were left under a 25-ton hydraulic press for three minutes to pelletize. Then, amounts of elements and compounds were measured in ppm using Wavelength Dispersive X-ray Fluorescence spectrometry. The activity concentration of the radionuclides was determined using a gamma spectrometer. The gamma in-situ measurement system calculated the outdoor gamma dose rates.

Soil radioactivity and terrestrial gamma dose rates, radioactivity in drinking water, outdoor gamma dose rates, and accumulation of metal (loid)s in soil and water were determined. Hazard Quotient (HQ) and Hazard Index (HI) of non-carcinogenic hazards, and the Excess Lifetime Cancer Risk (ELCR) due to metal(loid)s both in soil and drinking water were calculated by equations used as described by the United States Environmental Protection Agency (USEPA) and United Nations Scientific Committee on the Effects of Atomic Radiation (UNSCEAR) ${ }^{(8,26) .}$

\section{*Determination of the soil radioactivity and terrestrial gamma dose rate}

Soil samples were obtained from the uncultivated locations close to settlements. Open, flat, and undisturbed geographical locations with good water permeability were selected as the sampling points. The foreign bodies were removed, and the remaining soil was placed in clean, sealed, and labeled bags. The samples were dried at $105^{\circ} \mathrm{C}$ for $24 \mathrm{~h}$, grained, passed through $2 \mathrm{~mm}$ sieves, and placed in Marinelli type beakers. The samples were kept one month before the analysis at the airtight condition to allow secular equilibrium between thorium and radium and their decay products. Each sample was counted for $50000 \mathrm{~s}$ using a gamma spectroscopy device connected to a coaxial germanium detector, the CANBERRA $\mathrm{XtRa}$ in the accredited laboratories of Radioactivity Analysis and Measurement Department in Cekmece Nuclear Research and Training Center (CNRTC). The detector was shielded to reduce the background due to the cosmic rays and the radiation near the system. Full energy peak efficiency was determined using Standard Reference Material prepared by 
the International Atomic Energy Agency (22). The Minimum Detectable Activity (MDA) value for ${ }^{137} \mathrm{Cs}$ was obtained as $0.5 \mathrm{~Bq} / \mathrm{kg}$.

Based on the radioactivity levels of ${ }^{226} \mathrm{Ra}$, ${ }^{232} \mathrm{Th},{ }^{40} \mathrm{~K}$, and ${ }^{137} \mathrm{Cs}$ the gamma Absorbed Dose Rate in the Air (ADRA) in nGy h-1 at $1 \mathrm{~m}$ above the ground level was calculated using the following Equation (8, 26), Equation 1:

$\mathrm{ADCR}=\mathrm{aC}_{\mathrm{Ra}} \times \mathrm{bC}_{\mathrm{Th}} \times \mathrm{cC}_{\mathrm{K}} \times \mathrm{dC}_{\mathrm{Cs}}$

$\mathrm{C}_{\mathrm{Ra}}, \mathrm{C}_{\mathrm{Th}}, \mathrm{C}_{\mathrm{K}}$, and $\mathrm{C}_{\text {.C.s }}$ are the Activity Dose Rate Concentrations (Bq kg-1) of ${ }^{226} \mathrm{Ra},{ }^{232} \mathrm{Th},{ }^{40} \mathrm{~K}$, and ${ }^{137} \mathrm{Cs}$, respectively, in the soil sample. The values of a, b, c, and d are coefficients of $0.461,0.623$, 0.0417 and 0.1243 nGy $\mathrm{h}^{-1}\left(\mathrm{~Bq} \mathrm{~kg}^{-1}\right)^{-1}$, respectively $(8,26)$.

\section{*Determination of radioactivity in drinking water}

The water samples at predetermined sites were transported to the laboratory in $500 \mathrm{~cm}^{3}$ plastic bottles. Aroutine procedure of sample preparation was used for the radionuclide analyses (27). After being filtered through a paper, each sample was transferred to a beaker where a smallamount of nitric acid was added to avoid any precipitation on the container walls. After slow evaporation, the sample was moved to a stainless steel counting planchette to be evaporated at a low temperature. Following cooling and weighing for the dry residue, each sample was counted for gross-alpha and gross-beta radioactivities in a low-background proportional counter with the gas flow (Berthold, LB770-PC 10-Channel Low-Level Planchet Counter). The system was commonly used for measuring samples with low natural background radiation. The results were obtained in units of $\mathrm{Bq} \mathrm{dm}^{-3}$. The calibration of the low-level counting system used in the measurements was carried out with standard solutions that contained known activities of ${ }^{241} \mathrm{Am}$ for alphas and ${ }^{90} \mathrm{Sr}$ for betas. The following Equation was used to calculate the effective dose $\left(D R_{W}\right)$ due to drinking water radioactivity, Equation 2:

$\mathrm{DR}_{W}=A_{W} \times I R_{W} \times I D_{F} \times 2($ for both $\alpha$ and $\beta)$
$\mathrm{DR}_{\mathrm{w}}$ is the dose equivalent effective (Sv/year), $A_{W}$ is Activity $(\mathrm{Bq} / \mathrm{L}), \quad \mathrm{IR}_{\mathrm{w}}$ is the Intake of Water for one person in one year $(730 \mathrm{~L})$, and $\mathrm{ID}_{\mathrm{F}}$ is the ingestion effective dose equivalent factor for $3.58 \times 10^{-7} \mathrm{~Sv} / \mathrm{Bq}$ for alpha (28). ELCR value for 70 years of average life duration was calculated using the following Equation $(8,26)$, Equation 3:

$\mathrm{ELCR}=\mathrm{DR}_{\mathrm{W}} \times \mathrm{DL} \times \mathrm{RF}$

$D_{\mathrm{w}}$ is the annual effective dose equivalent (Sv/year), DL is the Duration of Life (70 years), and $\mathrm{RF}$ is a Risk Factor $\left(\mathrm{Sv}^{-1}\right)$. For risk assessment, the nominal probability coefficient of $7.3 \times 10^{-2} \mathrm{~Sv}^{-1}$ recommended by International Commission on Radiological Protection (ICRP) was adopted (29).

\section{*Determination of the outdoor gamma dose rates}

The outdoor gamma dose rates were determined in the summer. Readings were recorded 1 meter away from the ground at the same sites that soil samples were collected in the four different districts of the region (figure 1). The gamma dose rates were measured by a portable device (Thermo sci.) connected with high sensitivity NaI scintillation detector (NBR model of Thermo sci.) calibrated at the beginning of the study by the accredited Secondary Standard Dosimetry Laboratory (SSDL) of Cekmece Nuclear Research and Training Center (CNRTC). The measurements were performed in the air for two minutes, and the gamma dose rate units were recorded as $\mu \mathrm{R}^{-1}$ and then converted to $\mathrm{nGy} \mathrm{h}^{-1}$ using the conversion factor of $8.7 \mathrm{nGy} \mu \mathrm{R}^{-1}$. The Annual Effective Dose Equivalent (AEDE) was calculated using the following Equation (8,26), Equation 4:

$\mathrm{AEDE}=\mathrm{ADRA} \times \mathrm{DCF} \times \mathrm{OF} \times \mathrm{T}$

ADRA is Absorbed Dose Rate in the Air (nGy $\mathrm{h}^{-1}$ ), DCF is the dose conversion factor of $0.7, \mathrm{OF}$ is Occupancy Factor of 0.2 , and $\mathrm{T}$ is the time $\left(8760 \mathrm{~h} \mathrm{y}^{-1}\right)$. ELCR for 70 years of average life duration was calculated using the following Equation $(8,26)$, Equation 5:

Int. J. Radiat. Res., Vol. 18 No. 4, October 2020 
$\mathrm{ELCR}=\mathrm{AEDE} \times \mathrm{DL} \times \mathrm{RF}$

DL is the Duration of Life (70 y), and RF is the Risk Factor $\left(\mathrm{Sv}^{-1}\right)$, fatal cancer risk per sievert. For stochastic effects, RF of ICRP-103 for the public as 0.055 was used (29).

\section{*Determination of accumulation of metal (loid)s in soil and water}

To determine the number of trace elements in soil, the powdery soil samples were first weighed $12 \mathrm{~g}$, taking care that they were milled below 200 mesh and $3 \mathrm{~g}$ of cellulose were added and mixed for five minutes in an agate vat. The samples were pressed for three minutes using a 25-ton hydraulic press with $40 \mathrm{~mm}$ diameter steel pellet cups to make pellets. Then, the powder samples prepared were analyzed by Wavelength Dispersive X-Ray Fluorescence spectrometry, and quantities of elements were determined in $\mathrm{ppm}(\mu \mathrm{g} / \mathrm{g})$. To determine the number of trace elements in drinking water, calibration standard, and water sample solutions to be analyzed were prepared using $2 \%$ HNO3. The solutions were analyzed by Inductively Coupled Plasma-Optical Emission Spectrometry (ICP-OES) (Perkin Elmer Optima 7000 DV) method with autosampler by plotting calibration curves. Additionally, Mercury (Hg) analyzes were performed by ICP-OES/CFHG (Inductively Coupled Plasma - Optical Emission Spectrometry/Continuous Flow Hydride Generation) method. It was provided that the correlation coefficient of the calibration curves was at least $r^{2}=0,999$. The accuracy of the analysis results was tested with the certified standard reference material named "NIST SRM 1640a - Trace Elements in Natural Water" and quantities of elements were determined in ppm $(\mu \mathrm{g} / \mathrm{L})$. The potential exposure pathways for metal(loid)s in soil, and drinking water are calculated by following the Equations bellow (8, 26), Equation 6:

$$
A D I_{\text {Sing }}=\frac{C x I R \times E F \times E D \times C F}{B W \times A T}
$$

$\mathrm{ADI}_{\text {sing }}$ is the Average Daily Intake of metal (loid)s ingested from soil (mg/kg-day), $\mathrm{C}$ is the concentration of heavy metal $(\mathrm{mg} / \mathrm{kg})$ for soil,
IR is the Ingestion Rate (100 mg/day) (26), EF is the exposure frequency (350 days/year) (30), ED is the exposure duration (24 years), BW is the bodyweight of the exposed individual (70 kg), AT is the time over which the dose is averaged $(365 \times 70=25550$ days for carcinogens, $365 \times \mathrm{ED}$ days for non-carcinogens) (26), and CF is the conversion factor $\left(10^{-6} \mathrm{~kg} / \mathrm{g}\right)$, Equation 7 :

$A D I_{\text {Sinh }}=\frac{C \times I R_{\text {air }} \times E F \times E D}{B W \times A T \times P E F}$

$\mathrm{ADI}_{\mathrm{S} \text { inh }}$ is the average daily intake of metal (loid)s inhaled from soil (mg/kg-day), $\mathrm{C}$ is the concentration of heavy metal in soil $(\mathrm{mg} / \mathrm{kg}$ ), $\mathrm{IR}_{\text {air }}$ is the Inhalation Rate, $20 \mathrm{~m}^{3} /$ day, $\mathrm{PEF}$ is the particulate emission factor, $1.36 \times 109 \mathrm{~m}^{3} / \mathrm{kg}$ (26). $\mathrm{EF}, \mathrm{ED}, \mathrm{BW}$, and AT are as defined earlier above, Equation 8:

$A D I_{S d e m s}=\frac{C \times S A \times E F \times E D \times C F}{B W \times A T}$

$\mathrm{ADI}_{\text {s dems }}$ is the exposure dose from the soil via dermal contact (mg/kg-day), $\mathrm{C}$ is the concentration of heavy metal in soil (mg/kg), SA is exposed to the skin area, $3950 \mathrm{~cm}^{2}$, AF is the soil Adherence Factor in, $0.07 \mathrm{mg} / \mathrm{cm}^{2}$, ABS is the fraction of the applied dose absorbed across the skin $0.001(8,26)$. EF, ED, BW, CF, and AT are as defined earlier above, Equation 9:

$A D I_{W i n g}=\frac{C \times I R \times E F \times E D}{B W \times A T}$

ADIw ing is the Average Daily Intake of metal (loid)s ingested from water (mg/kg-day); C is the heavy metal concentration in water $(\mu \mathrm{g} / \mathrm{L})$, IRis the daily intake of water, $2.2 \mathrm{~L} \mathrm{day}^{-1}(8,26)$, ED is the exposure duration, 70 years (31), $\mathrm{EF}$ is the exposure frequency, 365 days/year (32), AT is the time over which the dose is averaged, $365 \times 70=$ 25550 days for both carcinogens and non-carcinogens (31), BW is the bodyweight of the exposed individual $(70 \mathrm{~kg})$. Non-carcinogenic hazards are characterized by a term called Hazard Quotient (HQ). HQ is a unitless number expressed as the probability of an individual suffering an adverse effect. It is defined as the quotient of ADI or dose divided by the toxicity threshold value, referred to as the chronic 
reference dose $\left(\mathrm{R}_{\mathrm{fD}}\right)$ in $\mathrm{mg} / \mathrm{kg}$-day of a specific heavy metal $(8,26)$, Equation 10:

$H Q=\frac{A D I}{R_{f D}}$

For $\mathrm{n}$ number of metal(loid)s, the non-carcinogenic effect to the population is a result of the summation of all the HQs due to individual metal(loid)s. Specifically, the total chronic hazard attributable to exposure to all contaminant of potential concerns through a single exposure pathway is known as a Hazard Index $(\mathrm{HI})^{(26)}$. The Equation below shows the mathematical representation of this parameter for metals(loids) in soil and drinking water $(8,26)$, Equation 11:

$$
H I=\sum_{k=1}^{n} H Q_{k}=\sum_{k=1}^{n} \frac{A D I_{k}}{R_{f D k}}
$$

$\mathrm{HQ}_{\mathrm{k}}, \mathrm{ADI}_{\mathrm{k}}$, and $\mathrm{R}_{\mathrm{fDk}}$ are values of heavy metal $k$. For carcinogens, the risks are estimated as the incremental probability of an individual developing cancer over a lifetime as a result of exposure to the potential carcinogen. The Equation for calculating the Excess Lifetime Cancer Risk (ELCR) due to metal(loid)s both in soil and drinking water is $(8,26)$, Equation 12 :

$$
E L C R=\sum_{k=1}^{n} A D I_{k} \times S F_{k}
$$

Excess Lifetime Cancer Risk values is a unitless probability of an individual developing cancer over a lifetime. $\mathrm{ADI}_{\mathrm{k}}(\mathrm{mg} / \mathrm{kg} /$ day $)$ and $\mathrm{SF}_{\mathrm{k}}$ $(\mathrm{mg} / \mathrm{kg} / \text { day })^{-1}$ are the average daily intake and the cancer slope factor, respectively, for the kth heavy metal, for $n$ number of metal(loid)s. The slope factor converts the estimated daily intake of the heavy metal averaged over a lifetime of exposure directly to the incremental risk of an individual developing cancer $(8,26)$.

In summary, descriptive statistics are given in tables as mean \pm standard deviation (SD). Categorical variables are summarized as numbers. Statistical analyses were evaluated using the IBM SPSS Statistics software v20.0 (IBM Corp., Armonk, NY, USA).

\section{RESULTS}

A total of 113 soil samples was collected from predetermined sites and then analyzed. Radionuclide concentrations $(\mathrm{Bq} / \mathrm{kg})$ for ${ }^{40} \mathrm{~K}$, ${ }^{226} \mathrm{Ra},{ }^{232} \mathrm{Th}$ and ${ }^{137} \mathrm{Cs}$ in soil samples were $441 \pm 182,13 \pm 12.6,14.1 \pm 5.2$, and 16.0 \pm 6.0 , respectively. Mean Absorbed Dose Rate values in Air (nGy/h) was meusured for outdoor as $82.4 \pm 18.1$, and calculated for outdoor and cosmic as $35.2 \pm 12.7$ and $47.3 \pm 16.3$, respectively. Radioactivity as gross $\alpha$ activity and gross $\beta$ activity in water were $0.053 \pm 0.04$ and $0.19 \pm 0.13$, respectively (table 1 ).

The average annual effective dose values $(\mathrm{mSv})$ resulting from terrestrial and cosmic gamma radiations were calculated as $0.04 \pm 0.02$ and $0.06 \pm 0.02$, respectively. Cosmic radiation exposure dose levels primarily depend on the altitude of the area. Accordingly, the average estimated excess cancer risk values were calculated as $1.78 \pm 0.88 \mathrm{E}-04$ and $2.39 \pm 0.04 \mathrm{E}-04$ for terrestrial and cosmic exposures, respectively. Annual cumulative biologic effective dose due to radiologic exposure that arises from radioactivity in drinking water in the region was determined as $27.83 \pm 24.81 \mu \mathrm{Sv}$. Accordingly, the average estimated excess cancer risk value was determined as 15.24 $\pm 13.6 \mathrm{E}-05$ (table 2).

The collected 113 soil and 43 water samples were also analyzed to find out health risks depending on metal(loid) accumulation in the research region. Mean metal(loid) concentration of $\mathrm{Cr}, \mathrm{Mn}, \mathrm{Ni}, \mathrm{Cu}, \mathrm{Zn}, \mathrm{As}$, and $\mathrm{Pb}$ in soil were determined as 222 (27-1235), 979 (550-2012), 128 (21-592), 52 (30-96), 112 (59-422), 11 (4-25), and 12 (7-34) $\mu \mathrm{g} / \mathrm{g}$, respectively and mean metal(loid) concentration of $\mathrm{Cd}, \mathrm{Cr}, \mathrm{Cu}, \mathrm{Ni}$, $\mathrm{Pb}, \mathrm{Zn}$, and $\mathrm{Ba}$ for $\mathrm{Cd}, \mathrm{Cr}, \mathrm{Cu}, \mathrm{Ni}, \mathrm{Pb}, \mathrm{Zn}$, and $\mathrm{Ba}$ in drinking water were determined as 0.3 (LDL1.1), 2.0 (LDL-9.1), 2.1 (LDL-25.8), 1.7 (LDL-3.8), 1.2 (LDL-4.2), 67.1 (LDL-2020), and 35.3 (1.5135.7) $\mu \mathrm{g} / \mathrm{L}$, respectively. The amount of metal (loid) concentration in water is related to interactions of water sources and their 
pathways. Therefore, distribution of metal (loid) $\mathrm{s}$ in water can be different from metals in soil (table 3).

Reference dose (Rfd) values and cancer slope factors (SF) for each metal(loid) were given in table 4. The non-carcinogenic hazard quotient (HQ) values were determined for $\mathrm{Cr}, \mathrm{Ni}, \mathrm{As}, \mathrm{Pb}$, $\mathrm{Zn}, \mathrm{Mn}$, and $\mathrm{Cu}$ in soil as $1.36 \mathrm{E}+00,1.69 \mathrm{E}-02$,
8.06E-02, 1.25E-02, 6.22E-04, 3.75E-02, and $3.25 \mathrm{E}-03$, respectively and for $\mathrm{Cd}, \mathrm{Cr}, \mathrm{Cu}, \mathrm{Ni}, \mathrm{Pb}$, $\mathrm{Zn}$, and $\mathrm{Ba}$ in water as 4.79E-01, 2.38E-01, 2.39E -02, 2.74E-02, 1.52E-01, 4.20E-02, and 5.56E-02, respectively. The mean excess lifetime cancer risk values due to metal(loid) exposure were as $\mathrm{Cr}<\mathrm{Ni}<\mathrm{As}$ in soil and as $\mathrm{Cr}<\mathrm{Cd}<\mathrm{Pb}$ in water (table 5).

Table 1. Radionuclide concentrations in soil, absorbed gamma dose rates and radioactivity in water.

\begin{tabular}{|c|c|c|c|c|c|c|c|c|c|}
\hline \multirow{2}{*}{ District } & \multicolumn{6}{|c|}{ Radionuclide Concentration (Bq/kg) } & \multicolumn{2}{|c|}{ Absorbed Dose Rate in Air (nGy/h) } & \multicolumn{2}{|c|}{ Radioactivity in Water (Bq/L) } \\
\cline { 2 - 10 } & ${ }^{226} \mathrm{Ra}$ & ${ }^{232} \mathrm{Th}$ & ${ }^{40} \mathrm{~K}$ & ${ }^{137} \mathrm{Cs}$ & $\begin{array}{c}\text { Outdoor } \\
\text { (measured) }\end{array}$ & $\begin{array}{c}\text { Outdoor } \\
\text { (calculated) }\end{array}$ & $\begin{array}{c}\text { Cosmic } \\
\text { (calculated) }\end{array}$ & $\begin{array}{c}\text { Gross } \boldsymbol{\alpha} \\
\text { Activity }\end{array}$ & $\begin{array}{c}\text { Gross } \boldsymbol{\beta} \\
\text { activity }\end{array}$ \\
\hline Aralık & $426 \pm 133$ & $6.3 \pm 3.7$ & $14.2 \pm 4.4$ & $13.9 \pm 3.5$ & $85.4 \pm 17.5$ & $\mathbf{3 1 . 2 \pm 6 . 2}$ & $\mathbf{5 4 . 2 \pm 1 8 . 0}$ & $0.069 \pm 0.045$ & $0.23 \pm 0.10$ \\
\hline Center & $436 \pm 148$ & $11.5 \pm 7.5$ & $15 \pm 4.8$ & $18.4 \pm 5.0$ & $87.1 \pm 16.8$ & $\mathbf{3 5 . 2} \pm 8.9$ & $\mathbf{5 1 . 9} \pm 14.8$ & $0.055 \pm 0.044$ & $0.20 \pm 0.13$ \\
\hline Karakoyunlu & $345 \pm 96$ & $8.5 \pm 6.5$ & $13.1 \pm 4.9$ & $13.0 \pm 4.6$ & $73.5 \pm 18$ & $28.1 \pm 9.4$ & $45.4 \pm 10.6$ & $0.089 \pm 0.051$ & $0.28 \pm 0.12$ \\
\hline Tuzluca & $486 \pm 231$ & $18.7 \pm 16.7$ & $13.8 \pm 6.1$ & $16.5 \pm 7.2$ & $81.1 \pm 18.8$ & $39.6 \pm 16.3$ & $41.5 \pm 16.7$ & $0.025 \pm 0.035$ & $0.10 \pm 0.07$ \\
\hline Igdir & $441 \pm 182$ & $13 \pm 12.6$ & $14.1 \pm 5.2$ & $16.0 \pm 6.0$ & $82.4 \pm 18.1$ & $35.2 \pm 12.7$ & $47.3 \pm 16.3$ & $0.053 \pm 0.047$ & $0.19 \pm 0.13$ \\
\hline
\end{tabular}

Average Values \pm Standart Deviation

Table 2. Health risks (ELCR) due to background radioactivity.

\begin{tabular}{|c|c|c|c|c|c|c|}
\hline \multirow{2}{*}{ District } & \multicolumn{2}{|c|}{ Terrestrial } & \multicolumn{2}{c|}{ Cosmic } & \multicolumn{2}{c|}{ Radioactivity in Water } \\
\cline { 2 - 7 } & $\begin{array}{c}\text { Annual Effective } \\
\text { Dose (mSv) }\end{array}$ & $\begin{array}{c}\text { Excess Lifetime } \\
\text { Cancer Risk }\end{array}$ & $\begin{array}{c}\text { Annual Effective } \\
\text { Dose }(\mathbf{m S v})\end{array}$ & $\begin{array}{c}\text { Excess Lifetime } \\
\text { Cancer Risk }\end{array}$ & $\begin{array}{c}\text { Annual Effective } \\
\text { Dose }(\boldsymbol{\mu S v})\end{array}$ & $\begin{array}{c}\text { Excess Lifetime } \\
\text { Cancer Risk }\end{array}$ \\
\hline Aralık & $0.03 \pm 0.01$ & $1.42 \pm 0.54 \mathrm{E}-04$ & $0.06 \pm 0.01$ & $2.30 \pm 0.37 \mathrm{E}-04$ & $12.81 \pm 18.14$ & $7.01 \pm 9.93 \mathrm{E}-05$ \\
\hline Center & $0.04 \pm 0.01$ & $1.58 \pm 0.53 \mathrm{E}-04$ & $0.07 \pm 0.02$ & $2.74 \pm 0.36 \mathrm{E}-04$ & $28.59 \pm 23.07$ & $15.65 \pm 12.63 \mathrm{E}-05$ \\
\hline Karakoyunlu & $0.04 \pm 0.01$ & $1.78 \pm 0.67 \mathrm{E}-04$ & $0.06 \pm 0.02$ & $2.63 \pm 0.18 \mathrm{E}-04$ & $35.98 \pm 23.54$ & $19.7 \pm 12.89 \mathrm{E}-05$ \\
\hline Tuzluca & $0.05 \pm 0.02$ & $2.00 \pm 1.11 \mathrm{E}-04$ & $0.05 \pm 0.02$ & $2.1 \pm-0.16 \mathrm{E}-04$ & $46.57 \pm 26.44$ & $25.5 \pm 14.48 \mathrm{E}-05$ \\
\hline Igdir & $0.04 \pm 0.02$ & $1.78 \pm 0.88 \mathrm{E}-04$ & $0.06 \pm 0.02$ & $2.39 \pm 0.04 \mathrm{E}-04$ & $27.83 \pm 24.81$ & $15.24 \pm 13.6 \mathrm{E}-05$ \\
\hline
\end{tabular}

Average Values \pm Standart Deviation

Table 3. Average concentration of certain metal(loid)s in soil and drinking water.

\begin{tabular}{|c|c|c|c|c|c|c|c|}
\hline \multicolumn{8}{|c|}{ Soil } \\
\hline \multirow{2}{*}{ District } & \multicolumn{7}{|c|}{ Metal(loid) Concentration ( $\mu \mathrm{g} / \mathrm{g})$} \\
\hline & $\mathrm{Cr}$ & Mn & $\mathrm{Ni}$ & $\mathrm{Cu}$ & $\mathrm{Zn}$ & As & $\mathbf{P b}$ \\
\hline Aralık & $247(27-373)$ & $863(550-1070)$ & $136(21-218)$ & $50(35-64)$ & $87(59-193)$ & $15(10-25)$ & $12(7-34)$ \\
\hline Center & $196(70-327)$ & 894 (616-1181) & $127(45-218)$ & $51(30-70)$ & $112(63-322)$ & $12(6-20)$ & $13(10-26)$ \\
\hline Karakoyunlu & $312(91-464)$ & $960(639-1156)$ & $167(36-243)$ & $50(37-55)$ & $76(65-92)$ & $13(12-15)$ & $10(8-12)$ \\
\hline \begin{tabular}{|l|} 
Tuzluca \\
\end{tabular} & $199(60-1235)$ & 1101 (642-2012) & $112(39-592)$ & $55(35-96)$ & $137(70-422)$ & $8(4-13)$ & $14(8-22)$ \\
\hline Igdir & $222(27-1235)$ & $979(550-2012)$ & $128(21-592)$ & $52(30-96)$ & $112(59-422)$ & $11(4-25)$ & $12(7-34)$ \\
\hline \multicolumn{8}{|c|}{ Drinking Water } \\
\hline \multirow{2}{*}{ District } & \multicolumn{7}{|c|}{ Metal(loid) Concentration ( $\mu \mathrm{g} / \mathrm{L}$ ) } \\
\hline & Cd & $\mathrm{Cr}$ & $\mathrm{Cu}$ & $\mathbf{N i}$ & $\mathbf{P b}$ & Zn & Ba \\
\hline Aralık & 0.7 (LDL-1.1) & $3.2(0.3-6)$ & 4.2 (LDL-14.9) & $1.9(1.2-2.7)$ & 1.3 (LDL-1.8) & $211.1(3.5-2020)$ & $42.6(1.5-60.2)$ \\
\hline Center & 0.1 (LDL-0.7) & 2 (LDL-8.9) & 1.4 (LDL-10.2) & $1.8(0.5-2.4)$ & $1.2(\mathrm{LDL}-2.7)$ & 16.6 (LDL-177.4) & $40.6(2.2-135.7)$ \\
\hline Karakoyunlu & 0.7 (LDL-1.1) & $3.6(0.2-9.1)$ & 3.4 (LDL-25.8) & $2.2(1.3-2.8)$ & 0.2 (LDL-1) & $72.0(0.4-354.2)$ & 67 (39.1-97.8) \\
\hline \begin{tabular}{|l|} 
Tuzluca \\
\end{tabular} & 0.1 (LDL-0.8) & 0.5 (LDL-1.1) & 0.9 (LDL-5.2) & 1.2 (LDL-3.8) & 1.8 (LDL-4.2) & 28.8 (LDL-411.8) & $9.8(1.9-24.9)$ \\
\hline Igdir & 0.3 (LDL-1.1) & 2.0 (LDL-9.1) & 2.1 (LDL-25.8) & 1.7 (LDL-3.8) & 1.2 (LDL-4.2) & 67.1 (LDL-2020) & $35.3(1.5-135.7)$ \\
\hline
\end{tabular}


Table 4. Reference dose values (Rfd) and cancer slope factors (SF). $(26,31,59)$

\begin{tabular}{|c|c|c|c|c|c|c|}
\hline \multirow{2}{*}{ Metal(loid) } & \multicolumn{3}{|c|}{$\mathbf{R}_{\mathrm{fD}}$ (mg/kg-day) } & \multicolumn{3}{c|}{ SF (mg/kg/day) $)^{-1}$} \\
\cline { 2 - 7 } & Oral & Inhalation & Dermal & Oral & Inhalation & Dermal \\
\hline $\mathbf{C r}$ & $3.00 \mathrm{E}-03$ & $2.86 \mathrm{E}-05$ & $6.00 \mathrm{E}-05$ & $5.01 \mathrm{E}-01$ & $4.20 \mathrm{E}+01$ & $2.00 \mathrm{E}+01$ \\
\hline $\mathbf{N i}$ & $2.00 \mathrm{E}-02$ & $2.06 \mathrm{E}-02$ & $5.40 \mathrm{E}-03$ & $1.70 \mathrm{E}+00$ & $8.40 \mathrm{E}-01$ & $4.25 \mathrm{E}+01$ \\
\hline $\mathbf{A s}$ & $3.00 \mathrm{E}-04$ & $3.00 \mathrm{E}-04$ & $1.23 \mathrm{E}-04$ & $1.50 \mathrm{E}+00$ & $1.51 \mathrm{E}+01$ & $1.50 \mathrm{E}+00$ \\
\hline $\mathbf{P b}$ & $3.50 \mathrm{E}-03$ & $3.52 \mathrm{E}-03$ & $5.25 \mathrm{E}-04$ & $8.50 \mathrm{E}-01$ & $\mathrm{NA}$ & $\mathrm{NA}$ \\
\hline $\mathbf{C d}^{(\mathbf{( W )}}$ & $5.00 \mathrm{E}-04$ & $1.00 \mathrm{E}-03$ & $1.00 \mathrm{E}-05$ & $1.50 \mathrm{E}+01$ & $\mathrm{NA}$ & $\mathrm{NA}$ \\
\hline $\mathbf{C d}^{(\mathbf{S})}$ & $1.00 \mathrm{E}-03$ & $1.00 \mathrm{E}-03$ & $1.00 \mathrm{E}-05$ & $3.80 \mathrm{E}-01$ & $6.30 \mathrm{E}+00$ & $3.80 \mathrm{E}-01$ \\
\hline $\mathbf{B a}$ & $2.00 \mathrm{E}-01$ & $\mathrm{NA}$ & $\mathrm{NA}$ & $\mathrm{NA}$ & $\mathrm{NA}$ & $\mathrm{NA}$ \\
\hline $\mathbf{Z n}$ & $3.00 \mathrm{E}-01$ & $3.00 \mathrm{E}-01$ & $6.00 \mathrm{E}-02$ & $\mathrm{NA}$ & $\mathrm{NA}$ & $\mathrm{NA}$ \\
\hline $\mathbf{M n}$ & $1.40 \mathrm{E}-01$ & $1.43 \mathrm{E}-05$ & $2.33 \mathrm{E}-02$ & $\mathrm{NA}$ & $\mathrm{NA}$ & $\mathrm{NA}$ \\
\hline $\mathbf{H g}$ & $1.00 \mathrm{E}-04$ & $8.57 \mathrm{E}-05$ & $2.10 \mathrm{E}-02$ & $\mathrm{NA}$ & $\mathrm{NA}$ & $\mathrm{NA}$ \\
\hline $\mathbf{C u}$ & $4.00 \mathrm{E}-02$ & $4.20 \mathrm{E}-02$ & $1.20 \mathrm{E}-02$ & $\mathrm{NA}$ & $\mathrm{NA}$ & NA \\
\hline
\end{tabular}

${ }^{\mathrm{w}}$ is for metal(loid) in Water, ${ }^{\mathrm{s}}$ is for metal(loid) in Soil, NA: Not Available.

Table 5. Health risk due to metal(loid) concentration in soil and drinking water.

\begin{tabular}{|c|c|c|c|c|c|c|c|c|c|c|}
\hline \multicolumn{11}{|c|}{ Soil } \\
\hline \multirow{2}{*}{ District } & \multicolumn{7}{|c|}{ Hazard Quotient (HQ) } & \multicolumn{3}{|c|}{ Excess Lifetime Cancer Risk } \\
\hline & $\mathrm{Cr}$ & $\mathbf{N i}$ & As & $\mathrm{Pb}$ & $\mathrm{Zn}$ & Mn & $\mathrm{Cu}$ & $\mathrm{Cr}$ & $\mathbf{N i}$ & As \\
\hline Aralık & $1.51 \mathrm{E}+00$ & $1.79 \mathrm{E}-02$ & 1.10E-01 & $1.25 \mathrm{E}-02$ & $4.92 \mathrm{E}-04$ & $3.32 \mathrm{E}-02$ & 3.13E-03 & $1.85 \mathrm{E}-03$ & $2.28 \mathrm{E}-03$ & 3.85E-05 \\
\hline Center & $1.91 \mathrm{E}+00$ & $2.22 \mathrm{E}-02$ & 9.52E-02 & 1.04E-02 & 4.30E-04 & $3.72 \mathrm{E}-02$ & 3.19E-03 & $8.58 \mathrm{E}-04$ & $2.83 \mathrm{E}-03$ & 3.34E-05 \\
\hline Karakoyunlu & $1.20 \mathrm{E}+00$ & 1.67E-02 & 8.79E-02 & $1.35 \mathrm{E}-02$ & 6.33E-04 & $3.44 \mathrm{E}-02$ & 3.19E-03 & $1.47 \mathrm{E}-03$ & $2.13 \mathrm{E}-03$ & 3.08E-05 \\
\hline Tuzluca & $1.20 \mathrm{E}+00$ & 1.46E-02 & 5.86E-02 & 1.35E-02 & 7.52E-04 & $4.22 \mathrm{E}-02$ & 3.44E-03 & 5.39E-04 & $1.86 \mathrm{E}-03$ & 2.05E-05 \\
\hline Igdir & $1.36 \mathrm{E}+00$ & 1.69E-02 & 8.06E-02 & $1.25 \mathrm{E}-02$ & $6.22 \mathrm{E}-04$ & $3.75 \mathrm{E}-02$ & $3.25 \mathrm{E}-03$ & $1.67 \mathrm{E}-03$ & $2.16 \mathrm{E}-03$ & 2.82E-05 \\
\hline \multicolumn{11}{|c|}{ Drinking Water } \\
\hline \multirow{2}{*}{ District } & \multicolumn{7}{|c|}{ Hazard Quotient (HQ) } & \multicolumn{3}{|c|}{ Excess Lifetime Cancer Risk } \\
\hline & Cd & $\mathrm{Cr}$ & $\mathrm{Cu}$ & $\mathbf{N i}$ & $\mathbf{P b}$ & Zn & $\mathrm{Ba}$ & Cd & $\mathrm{Cr}$ & $\mathbf{P b}$ \\
\hline Aralık & $5.16 \mathrm{E}-01$ & 3.38E-01 & 3.62E-02 & 2.94E-02 & $1.25 \mathrm{E}-01$ & 2.22E-01 & 6.71E-02 & $3.87 \mathrm{E}-03$ & 5.07E-04 & 3.72E-06 \\
\hline Center & - & 2.67E-01 & 1.39E-02 & 2.83E-02 & 1.38E-01 & $2.32 \mathrm{E}-02$ & 6.39E-02 & - & $4.00 \mathrm{E}-04$ & 4.10E-06 \\
\hline Karakoyunlu & 4.79E-01 & 3.75E-01 & 4.46E-02 & 3.42E-02 & - & 7.55E-02 & 1.05E-01 & 3.59E-03 & $5.62 \mathrm{E}-04$ & - \\
\hline Tuzluca & - & 5.88E-02 & 1.36E-02 & 2.14E-02 & 1.90E-01 & $3.55 \mathrm{E}-02$ & 1.54E-02 & - & $8.82 \mathrm{E}-05$ & 5.65E-06 \\
\hline Igdir & 4.79E-01 & 2.38E-01 & 2.39E-02 & $2.74 \mathrm{E}-02$ & 1.52E-01 & $4.20 \mathrm{E}-02$ & 5.56E-02 & 3.59E-03 & 3.57E-04 & 4.52E-06 \\
\hline
\end{tabular}

\section{DISCUSSION}

In this study, the integral health risks due to two crucial environmental pollutants, radionuclides, and metal(loid)s were investigated for Igdir province. Radiation exposure is accepted as a risk factor for cancerous and non-cancerous health problems ${ }^{7}$ -12). EPA has classified As and Hexavalent $\mathrm{Cr}$ as Group A-human carcinogen, $\mathrm{Cd}$, and $\mathrm{Pb}$ as a Group B -probable human carcinogen, while $\mathrm{Cu}$ is accepted as Group D - not classifiable as to carcinogenicity in humans (26,33). Concerning carcinogenic health risk, excess lifetime cancer risk values were determined using equation 12 .
It was determined that the estimated mean excess lifetime cancer risk values due to metal (loid) exposure were as $\mathrm{Cr}<\mathrm{Ni}<\mathrm{As}$ in soil and as $\mathrm{Cr}<\mathrm{Cd}<\mathrm{Pb}$ in water.

HQ and HI values due to metal(loid) exposure were determined to be lower than the permissible maximum values for both soil and drinking water. Thus, the soil and the water of the region are unpolluted with metal(loid)s. Relatively low hazard indices suggest that the population is currently not at any imminent health risk because of metal(loid)s. Table 6 presents background radiation studies conducted in various other regions, and table 7 presents environmental metal(loid) studies 
conducted in different cities around the world.

The determined average values of radionuclide and gross alpha and beta mean activities for the region were in the ranges of the values found in other regions of Turkey (28,34-36, 42,43). However, the average value of ADRA for

Table 6. Background radioactivity studies carried out in different regions. ${ }^{(27,28,35,36,38-44)}$

\begin{tabular}{|c|c|c|c|c|c|c|c|c|}
\hline \multirow{2}{*}{ Referance } & \multirow{2}{*}{ Location } & \multirow{2}{*}{$\begin{array}{c}\text { ADRA } \\
\left(\mathrm{nGy} / \mathrm{h}^{-1}\right)\end{array}$} & \multicolumn{4}{|c|}{ Activity in Soil (Bq/kg) } & \multicolumn{2}{|c|}{ Activity in Water (mBq/L) } \\
\hline & & & ${ }^{40} \mathrm{~K}$ & ${ }^{226} \mathrm{Ra}$ & ${ }^{232} \mathrm{Th}$ & ${ }^{137} \mathrm{Cs}$ & Gross- $\alpha$ & Gross- $\beta$ \\
\hline Taşkın et al. ${ }^{(38)}$ & Kırklareli, Turkey & 118 & 667 & 37 & 40 & 8 & - & - \\
\hline Karahan et al. ${ }^{(27)}$ & Istanbul, Turkey & 65 & 342 & 21 & 37 & - & 23 & 70 \\
\hline $\begin{array}{l}\text { Karahan et al. }{ }^{(35)} \\
\text { Taşkın et al. }{ }^{\left({ }^{36)}\right.}\end{array}$ & Bursa, Turkey & 90 & 430 & 60 & - & 5 & 69 & 67 \\
\hline Kapdan et al. ${ }^{(40)}$ & Balikesir, Turkey & 127 & 675 & - & 55 & 3 & - & - \\
\hline Kapdan et al. ${ }^{(39)}$ & Çankırı, Turkey & 70 & 357 & - & 22 & 4 & 250 & 260 \\
\hline $\begin{array}{l}\text { Değerlier et al. }{ }^{(41)} \\
\text { Değerlier et al. }{ }^{(42)}\end{array}$ & Adana, Turkey & 67 & 298 & & 21 & 7 & 10 & 86 \\
\hline $\begin{array}{c}\text { Kobya et al. }{ }^{(28)} \\
\text { Kucukomeroglu et al. }{ }^{(43)}\end{array}$ & Artvin, Turkey & - & 358 & - & 19 & 54 & 46 & 91 \\
\hline Zhang $2017^{(57)}$ & Xitulvye, China & 78 & 396 & 49 & 63 & - & - & - \\
\hline Khan et al. ${ }^{(44)}$ & $\begin{array}{c}\text { North Waziristan, } \\
\text { Pakistan }\end{array}$ & - & 453 & 69 & 123 & - & - & - \\
\hline WHO, ${ }^{(37)}$ & & - & - & - & - & - & 500 & 1000 \\
\hline $\begin{array}{l}\text { Worldwide Average } \\
\text { (UNSCEAR 2018) }^{(8)}\end{array}$ & & 54 & 400 & 35 & 30 & - & - & - \\
\hline Present Study & Igdir, Turkey & 82 & 441 & 13 & 14 & 16 & 53 & 190 \\
\hline
\end{tabular}

Table 7. Metal(loid) studies carried out in different cities around the world ${ }^{(19,21,45-56)}$

\begin{tabular}{|c|c|c|c|c|c|c|c|c|}
\hline \multirow{2}{*}{ Reference } & \multirow{2}{*}{ Location } & \multicolumn{7}{|c|}{ Soil $(\mu \mathrm{g} / \mathrm{g})$} \\
\hline & & $\mathrm{Cr}$ & Mn & $\mathbf{N i}$ & $\mathrm{Cu}$ & $\mathrm{Zn}$ & $\mathbf{P b}$ & As \\
\hline De Miguel et al. ${ }^{(45)}$ & Madrid, Spain & 75 & 437 & 14 & 72 & 210 & 161 & - \\
\hline Lux et al. ${ }^{(46)}$ & Hamburg, Germany & 95 & 750 & 63 & & 516 & 218 & - \\
\hline Hu et al..$^{(47)}$ & Nanjing, China & 12 & 32 & 16 & 29 & 61 & 60 & 48 \\
\hline Chen et al. ${ }^{(19)}$ & Hong Kong & - & - & - & 16 & 59 & 90 & 17 \\
\hline Navas et al. ${ }^{(48)}$ & Aragon, Spain & 21 & 320 & 19 & 10 & 56 & 8 & 12 \\
\hline Wei et al. ${ }^{(21)}$ & Zhejiang, China & 48 & - & - & - & - & 69 & 16 \\
\hline Ruiz-Cortes et al. ${ }^{(49)}$ & Sevilla, Spain & 41 & 368 & 22 & 41 & 121 & 146 & - \\
\hline Present Study & Igdir, Turkey & 222 & 979 & 128 & 52 & 112 & 12 & 11 \\
\hline \multirow{2}{*}{ Reference } & \multirow{2}{*}{ Location } & \multicolumn{7}{|c|}{ Drinking-Water $(\mu \mathrm{g} / \mathrm{L})$} \\
\hline & & $\mathrm{Cr}$ & $\mathrm{Ba}$ & $\mathbf{N i}$ & $\mathrm{Cu}$ & $\mathrm{Zn}$ & $\mathrm{Pb}$ & Cd \\
\hline Waseem et al. ${ }^{(50)}$ & Sialkot, Pakistan & 0,030 & - & 0,10 & 0,06 & 0,2 & 0,49 & - \\
\hline Waseem et al. ${ }^{(50)}$ & Karachi, Pakistan & 0,012 & - & 0,04 & 0,12 & - & 0,01 & - \\
\hline Turdi et al. ${ }^{(51)}$ & Dawanqi, China & 3,790 & - & 0,86 & - & 4,5 & 0,04 & 0,008 \\
\hline Turdi et al. ${ }^{(51)}$ & Keyiri, China & 2,520 & - & 1,22 & - & 1,8 & 0,05 & 0,016 \\
\hline Huseyinli et al. ${ }^{(52)}$ & Oguz-Gabala PL, Azerbaijan & 0,530 & 110 & 1,89 & 3,89 & 14,2 & 1,63 & 0,570 \\
\hline Ahmad et al. ${ }^{(53)}$ & Sungai Petani, Malaysia & 2,190 & - & 5,63 & - & - & 5,18 & 2,810 \\
\hline Bajwa et al. ${ }^{(54)}$ & SW-Punjab, India & 28,300 & - & 35,00 & 145 & 833 & 46,0 & - \\
\hline Arain et al. ${ }^{(55)}$ & Bannu, Pakistan & - & 10046 & 1,73 & 10 & 235 & - & - \\
\hline Kruawal et al. ${ }^{(56)}$ & Bangkok, Thailand & - & 43 & 0,3 & - & 250 & - & - \\
\hline Ahmad et al. ${ }^{(58)}$ & Kulim, Malaysia & 0,1 & - & 0,59 & - & - & 0,56 & 0,31 \\
\hline USEPA $^{(26)}$ & & 100 & - & - & - & - & 15 & 5 \\
\hline WHO, 2011 ${ }^{(37)}$ & & 50 & & 70 & & & 10 & 3 \\
\hline Present Study & Igdir, Turkey & 2,270 & 35 & 1,74 & 2,10 & 67 & 1,20 & 0,300 \\
\hline
\end{tabular}

Int. J. Radiat. Res., Vol. 18 No. 4, October 2020 
the research region is quite high (8) and that could be explained by the effects of cosmic radiation due to the higher altitude of the region compared to other regions in the country. Moreover, it was seen that beta activity was higher than the values in other cities; on the contrary, the alpha activity in the region was respectively has lower values. This should be the result of the positive relation between alpha activity with the radium and thorium activities (e.g., Adana versus Igdir).

When the metal(loid) concentrations determined for soil were compared with the values of the other cities, it is seen that the concentrations of non-carcinogenic metals in the region are higher than those of the investigated cities. However, values for carcinogen heavy metals such as As and $\mathrm{Pb}$ are lower. This might be related to that a large part of Igdir consists of rural areas, and that the soil structure of rural areas has rich geochemical characteristics. However, this situation is entirely different for the concentration of the metal(loid)s in the water. The determined radionuclide concentrations in soil and alpha-beta activity in water were in the range of studies carried out in other regions in Turkey and close to worldwide averages. However, as expected, the average outdoor GDR determined for the region has the highest value determined in Turkey, which arises from the cosmic radiation effect due to the very high altitude of the region. Besides, alpha-beta activity and concentration of all metal(loid)s in water were found lower than the permissible maximum limits specified by WHO (37).

In the present investigation, it was observed that all parameters for radiation hazards were lower than the permissible maximum values. Thus, the soil of the studied area can be used by the residents without any serious radiological hazards. Radiation exposure may lead to an increased incidence of cancer. Exposed individuals should be studied for an extended period. Cancer risk increases due to exposure to moderate and high doses of radiation. However, our knowledge of the risk by acute low doses or low dose rates is limited. Therefore, the dose-response relation needs to be investigated by further molecular epidemiological studies in the future.

This is the first report on the environmental health risk assessment due to pollutants of radionuclides and metal(loid)s for the Turkish side of the border, in the vicinity of Metsamor Nuclear Power Plant, which has a risky condition. The emergency response system and evacuation plans are needed urgently. Based on the measurements of this study, currently, there are no health risks to the public for using the water and the soil of the region. Further studies should address the other kinds of pollutants as well for preventing or minimizing the harm from environmental pollution. More measures should be taken to control pollution and protect public health. The authors hope the findings obtained in this research will be useful for further studies to assess the doses of radioactivity and metal (loid) concentrations, which would help to formulate regional regulations for permissible levels.

\section{CONCLUSION}

Igdir Province of Turkey is only $\sim 20 \mathrm{~km}$ away from the Metsamor Nuclear Power Plant in Armenia. Measured levels of background radioactivity, as well as the concentration of radionuclide and metal(loids) in the soil and drinking water samples, indicate that currently, there is no health risk in the region. This study may become a valuable baseline for future research that aims to monitor the impacts of this aging plant built with Soviet-era technology. Attention should also be paid to radionuclide and metal(loid)s pollution in the water and soils for the safety and health of the local population. Although metal(loid)s in the soil samples did not seem harmful to human beings, monitorisation and protective measures must be taken to protect the environment. Primary healthcare professionals are uniquely suited to take a leadership role in the education of the public on the issues of environmental pollution and protection from radiation and metal(loid) exposure.

Int. J. Radiat. Res., Vol. 18 No. 4, October 2020 


\section{ACKNOWLEDGMENTS}

The authors would like to express their gratitude to Cekmece Nuclear Research and Training Center for providing relevant technical data and laboratory support for carrying out this research.

Funding source: Declared none.

Conflicts of interest: Declared none.

\section{REFERENCES}

1. Bennett LE, Burkhead JL, Hale KL, Tery N, Pilon M, PilonSmits EAH (2013) Analysis of transgenic Indian mustard plants for Phytoremediation of metal-contaminated mine tailings. Journal of Environmental Quality, 32: 432-440.

2. Lu Y, Yin W, Huang LB, Zhang GL, Zhao YG (2011) Assessment of bio-accessibility and exposure risk of arsenic and lead in urban soils of Guangzhou City, China. Environmental Geochemical Health, 33: 93-102.

3. Park RM, Bena JF, Stayner LT, Smith RJ, Gibb HJ, Lees PS (2004) Hexavalent chromium and lung cancer in the chromate industry: a quantitative risk assessment. Risk Analysis, 24: 1099-1108.

4. Ademola AK, Moronfolu AO, Peter OA (2015) Radiological safety assessment and determination of heavy metals in soil samples from waste dumpsites in Lagos and Ogun State, South-western, Nigeria. Journal of Radiation Research and Applied Sciences, 8: 148-153.

5. Pejman A, Bidhendi GN, Ardestani M, Saeedi M, Baghvand V (2015) A new index for assessing heavy metals contamination in sediments: A case study. Ecological Indicators, 58: 365-373.

6. Usikalu MR, Maleka PP, Malik M, Oyeyemi KD, Adewoyin OO (2015) Assessment of geogenic natural radionuclide contents of soil samples collected from Ogun State, Southwestern, Nigeria. Int J Radiat Res, 13: 355-361.

7. Kamiya K, Ozasa K, Akiba S, Niwa O, Kodama K, Takamura $\mathrm{N}$, Zaharieva EK, Kimura Y, Wakeford R (2015) Long-term effects of radiation exposure on health. Lancet, 1: 386 (9992), 469- 478.

8. UNSCEAR (2018) United Nations Scientific Committee on the Effects of Atomic Radiation Reports. Sources, Effects and Risks of Ionizing Radiation, 1982- 2017. https:// www.unscear.org/unscear/en/publications/2017.html. [Accessed in July 2019.]

9. Yamada M, Wong FL, Fujiwara S, Akahoshi M, Suzuki G (2004) Non-cancer disease incidence in atomic bomb survivors, 1958-1998. Radiation Research, 161: 622-632.

10. Adams MJ, Grant EJ, Kodama K (2012) Radiation dose associated with renal failure mortality: a potential pathway to partially explain increased cardiovascular disease mortality observed after whole-body irradiation. Radiation Research, 177: 220-228.
11. Sera N, Hida A, Imaizumi M, Nakashima E, Akahoshi M (2013) The association between chronic kidney disease and cardiovascular disease risk factors in atomic bomb survivors. Radiation Research, 179: 46-52.

12. Takahashi I, Abbott RD, Ohshita T (2012) A prospective follow-up study of the association of radiation exposure with fatal and non-fatal stroke among atomic bomb survivors in Hiroshima and Nagasaki (1980-2003). BMJ Open, 2: e000654.

13. Vernon RE (2013) Which Elements Are Metalloids? Journal of Chemical Education, 90(12): 1703-1707.

14. Ali $\mathrm{H}$ and Khan E (2017) What are heavy metals? Longstanding controversy over the scientific use of the term "heavy metals" - proposal of a comprehensive definition. Toxicological \& Environmental Chemistry, 100(1): 6-19.

15. Landis WG, Sofield RM, Yu MH (2000) Introduction to Environmental Toxicology. Molecular Substructures to Ecological Landscapes. 4th: CRC Press, 269.

16. Singh R, Gautam N, Mishra A, Gupta R (2011) Heavy metals and living systems: An overview. Indian Journal of Pharmacology, 43(3): 246-253.

17. Csuros M and Csuros C (2002) Environmental sampling and analysis for metals. Lewis Publishers, Boca Raton.

18. Ercal N, Gurer-Orhan H, Aykin-Burns N (2001) Toxic metals and oxidative stress Part I: Mechanisms involved in metalinduced oxidative damage. Current Topics in Medical Chemistry, 1(6): 529-539.

19. Chen TB, Wong JWC, Zhou HY, Wong MH (1997) Assessment of Trace Metal Distribution and Contamination in Surface Soils of Hong Kong. Environmental Pollution, 96 (1): 61-68.

20. Chale FMM (2002) Trace metal concentrations in water, sediments and fish tissue from Lake Tanganyika. Science of the Total Environment, 299: 115-21.

21. Wei B and Yang L (2010) A review of heavy metal contaminations in urban soils, urban road dusts and agricultural soils from China. Microchemical Journal, 94: 99-107.

22. IAEA-TECDOC-1421 (2004) Experience gained from fires in nuclear power plants: Lessons Learned. ISBN 978-92-0112604-7.

23. Salbu B and Skipperud L (2008) Nuclear Risk in Central Asia. Springer Science \& Business Media. pp 140. ISBN 978 -1-4020-8317-4.

24. Kindap T, Turuncoglu UU, Chen SH, Unal A, Karaca M (2009) Potential threats from a likely nuclear power plant accident: a climatological trajectory analysis and tracer study. Water, Air, and Soil Pollution, 198(1-4): 393-405.

25. Nuclear Power in Armenia. Archived from the original on 2016-03-24. https://world-nuclear.org. [Accessed in July 2019.]

26. USEPA (U.S. Environmental Protection Agency), Integrated Risk Information System (IRIS). http://www.epa.gov/iris. [Accessed in July 2019.]

27. Karahan G, Ozturk N, Bayülken A (2000) Natural radioactivity in various surface waters in Istanbul, Turkey. Water Res, 3418: 4367-4370.

28. Kobya Y, Taşkın H, Yeşilkanat CM, Çevik U, Karahan G, Çakır B (2015) Radioactivity Survey and Risk Assessment Study for Drinking Water in the Artvin, Turkey. Water, Air, and Soil Pollution, 226: 49.

29. ICRP-103 (2007) Recommendations of the International Commission on Radiological Protection (ICRP). ICRP Publication 103 Annals of the ICRP 37, 2-4.

30. Qing X, Yutong Z, Shenggao L (2015) Assessment of heavy 
metal pollution and human health risk in urban soils of steel industrial city (Anshan), Liaoning, Northeast China. Ecotoxicol Environ Saf, 120: 377-385.

31. Zhang L, Mo Z, Qin J, Li Q, Wei Y, Ma S, Xiong Y, Liang G, Qing L, Chen Z, Yang X, Zhang Z, Zou Y (2015) Change of water sources reduces health risks from heavy metals via ingestion of water, soil, and rice in a riverine area, South China. Science of the Total Environment, 530-531 163170.

32. Rasool A, Xiaoa T, Farooqic A, Shafeequed M, Masoode S, Alif S, Fahadg S, Nasimh W (2016) Arsenic and heavy metal contaminations in the tube well water of Punjab, Pakistan and risk assessment: A case study. Ecological Engineering, 95: $90-100$.

33. US FDA (United States Food and Drug Administration) 2015. Q3D Elemental Impurities Guidance for Industry (PDF) (Report). United States Department of Health and Human Services. p. 41. (Retrieved 15 February 2017)

34. Durusoy A and Yildirim M (2017) Determination of radioactivity concentrations in soil samples and dose assessment for Rize Province, Turkey. Journal of Radiation Research and Applied Sciences, 10(4): 348-352.

35. Karahan G (2010) Risk assessment of baseline outdoor gamma dose rate levels study of natural radiation sources in Bursa, Turkey. Radiation Protection Dosimetry, 142(24): 324-331.

36. Taşkın H, Kam E, Bozkurt A (2012) Determination of gross alpha and beta activity concentrations in drinking waters in Bursa region of north-western Turkey. Desalination and Water Treatment, 45: 1-3, 21-25.

37. WHO (2011) Guidelines for Drinking- Water Quality, fourth ed. Geneva. World Health Organization.

38. Taşkın H, Karavus M, Ay P, Topuzoglu A, Hidiroglu S, Karahan $G$ (2009) Radionuclide concentrations in soil and lifetime cancer risk due to gamma radioactivity in Kırklareli, Turkey. Journal of Environmental Radioactivity, 100: 4953.

39. Kapdan E, Taşkın H, Kam E, Osmanlıoğlu AE, Karahan G, Bozkurt A (2011) Study of Environmental Radioactivity Measurements for Cankırı, Turkey. Radiation Protection Dosimetry, 150(3): 398-404.

40. Kapdan E, Varinlioglu A, Karahan G (2012) Outdoor radioactivity and health risks in Balıkesir, northwestern Turkey. Radiation Protection Dosimetry, 148(3): 301-309.

41. Değerlier M, Karahan G, Ozger G (2008) Radioactivity concentrations and dose assessment for soil samples around Adana, Turkey. Journal of Environmental Radioactivity, 99: 1018-1025.

42. Değerlier M and Karahan G (2010) Natural radioactivity in various surface waters in Adana, Turkey. Desalination, 261: 126-130.

43. Kucukomeroglu B, Yesilbag YO, Kurnaz A, Celik N, Cevik U, Celebi N (2011) Radiological Characterisation of Artvin and Ardahan Provinces of Turkey. Radiation Protection Dosimetry. 145(4): 389-39.

44. Khan IU, Qin Z, Xie T, Bin Z, Li H, Sun W, Lewis E (2020) Evaluation of health hazards from radionuclides in soil and rocks of North Waziristan, Pakistan. Int Radiat Res, 18(2): 243-253.

45. De Miguel E, Jimenez de Grado J, Llamas JF, MartinDorado A, Mazadiego LF (1998) The overlooked contribution of compost application of the trace element load in the urban soil of Madrid (Spain). Science of the Total Environment, 215: 113-122.

46. Lux W (1986) Shhwermetallgehalte und isoplethen in Boden, subhydrishen Ablagerung und Pflanzenim Sudosten Hamburgs. Hamburger BodenkudlicheArbeiten, 5: 249.

47. Hu X, Zhang Y, Ding Z, Wang T, Lian H, Sun Y, Wu J (2012) Bioaccessibility and health risk of arsenic and heavy metals ( $\mathrm{Cd}, \mathrm{Co}, \mathrm{Cr}, \mathrm{Cu}, \mathrm{Ni}, \mathrm{Pb}, \mathrm{Zn}$ and $\mathrm{Mn}$ ) in TSP and PM 2.5 in Nanjing, China. Atmospheric Environment, 57: 146-152.

48. Navas A and Machin J (2002) Spatial distribution of heavy metals and arsenic in soils of Aragon (northeast Spain): controlling factors and environmental implications. $A p$ plied Geochemistry, 17: 961-973.

49. Ruiz-Cortes E, Reinoso R, Diaz-Barrientos E, Madrid L (2005) Concentrations of potentially toxic metals in urban soils of Seville: relationship with different land uses. Environmental Geochemistry and Health, 27: 465-474.

50. Waseem A, Arshad J, Iqbal F, Sajjad A, Mehmood Z, Murtaza G (2014) Pollution Status of Pakistan: A Retrospective Review on Heavy Metal Contamination of Water, Soil, and Vegetables. BioMed Research International, 813206.

51. Turdi $M$ and Yang $L$ (2016) Trace elements contamination and human health risk assessment in drinking water from the agricultural and pastoral areas of Bay County, Xinjiang, China. Int J Environ Res, Public Health. 13: 938.

52. Huseyinli AA, Hajiyeva S, Yolchiyeva F, Nazarov E (2016) Chemical analysis of Drinking Water Samples from Oguz Gabala Baku Pipeline. Journal of Natural Sciences, 4(1): 25 -34 .

53. Ahmad N, Jaafar MS, Alsaffar MS (2015) Study of radon concentration and toxic elements in drinking and irrigated water and its implications in Sungai Petani, Kedah, Malaysia. Journal of Radiation Research and Applied Sciences, 8 : 294 -299.

54. Bajwa BS, Kumar S, Singh S, Sahoo SK, Tripathi RM (2017) Uranium and other heavy toxic elements distribution in the drinking water samples of SW-Punjab. India Journal of Radiation Research and Applied Sciences, 10: 13-19.

55. Arain MB, Ullah I, Niaz A, Shah N, Shah A, Hussain Z, Tariq M, Afridi HI, Baig JA, Kazi TG (2014) Evaluation of water quality parameters in drinking water of district Bannu, Pakistan: Multivariate study. Sustainability of Water Quality and Ecology, 3-4: 114-123.

56. Kruawal K, Sachern F, Werner A, Müller J, Knepper TP (2005) Chemical water quality in Thailand and its impacts on the drinking water production in Thailand. Science of the Total Environment, 340: 57-70.

57. Xiaolan Z (2017) Radioactivity level of soil around a coalfired thermal power plant of northwest China. Int J Radiat Res, 15(3): 321-324.

58. Ahmad N, Jaafar MS, Nasir T, Rafique M (2018) Determination of radon concentration and heavy metals $(\mathrm{Ni}, \mathrm{Pb}, \mathrm{Cd}$, As, $\mathrm{Cr}$ ) in drinking and irrigated water sampled from Kulim, Malaysia. Int J Radiat Res, 16(3): 341-349.

59. Li H, Ji H, Shi C, Gao Y, Zhang Y, Xu X, Ding H, Tang L, Xing Y (2017) Distribution of $h$ heavy metals and metalloids in bulk and particle size fractions of soils from coal-mine brownfield and implications on human health. Chemosphere, 172: 505-515. 